\title{
Choroidal Changes in Patients with Familial Mediterranean Fever
}

\author{
Mustafa Kosker Tolga Bicer Osman Celikay Canan Gurdal \\ Diskapi Yildirim Beyazit Training and Research Hospital, Department of Ophthalmology, Ankara, Turkey
}

\section{Dear Editor}

We read with interest the article by Gundogan et al. entitled 'Choroidal Thickness Changes in the Acute Attack Period in Patients with Familial Mediterranean Fever' [1]. They concluded that the choroidal thickness was significantly thicker in patients with familial Mediterranean fever (FMF) compared to healthy controls during an acute attack.

We recently performed a study evaluating the choroidal thickness in chronic FMF patients without acute FMF attack (unpublished data). This helped us to see the effect of chronic nature of inflammation on choroid and posterior structures. In our study, we found that the choroid was statistically thinner in patients with FMF than in controls (unpublished data) in contrast to the study by Gundogan et al. We only included the patients with both clinically and genetically diagnosed FMF. Thus, we think this lowers the false positive risk and increases the sensitivity of the study. We are wondering whether all patients in Gundogan et al.'s study had MEFV gene mutations, and if so, whether there was any genotype-phenotype correlation? Because M694V mutations, especially in a homozygous form, have been found to be associated with more severe forms of the disease, earlier age of onset, and higher frequencies of arthritis and arthralgia $[2,3]$. Furthermore, Kosker et al. [4] reported that patients with M694V and M680I mutations might have a high risk for developing keratoconus, which is consistent with the previous genotype- phenotype correlation studies. It would also be interesting to know the changes in choroidal thickness after the acute attack of FMF.

In a few studies, colchicine had effects on optic nerve and retina pigment epithelium $[5,6]$. We are also wondering if there was any effect of colchicine on the choroid. May the changes observed in the choroid have been secondary to the colchicine treatment? It would be interesting to perform a study by including newly diagnosed patients with FMF who were not on colchicine and chronic FMF patients who were on colchicine to be able to further understand the effect of colchicine on the choroid and retina.

\section{References}

1 Gundogan FC, Akay F, Uzun S, Ozge G, Toyran S, Genç H: Choroidal thickness changes in the acute attack period in patients with familial Mediterranean fever. Ophthalmologica 2015, DOI: $10.1159 / 000442216$.

-2 Shohat M, Magal N, Shohat T, Chen X, Dagan T, Mimouni A, Danon Y, Lotan R, Ogur G, Sirin A, Schlezinger M, Halpern GJ, Schwabe A, Kastner D, Rotter JI, Fischel-Ghodsian N: Phenotype-genotype correlation in familial Mediterranean fever: evidence for an associa- tion between Met694Val and amyloidosis. Eur J Hum Genet 1999;7:287-292.

- 3 Pasa S, Altintas A, Devecioglu B, Cil T, Danis R, Isi H, Bayan K, Tuzun Y, Ecer S, Batun S, Ayyildiz O: Familial Mediterranean fever gene mutations in the Southeastern region of Turkey and their phenotypical features. Amyloid 2008;15:49-53.

4 4 Kosker M, Arslan N, Alp MY, Ozisler C, Acar M, Dogan AS, Yesilyurt A, Gurdal C: Association between keratoconus and familial
Mediterranean fever in Turkey. Cornea 2016; 35:77-80.

5 Hashimoto M, Asayama K, Matsumura M, Ogino N: Morphological effects of cytochala$\sin \mathrm{B}$ and colchicine on cultured retinal pigment epithelium (in Japanese). Nippon Ganka Gakkai Zasshi 1982;86:557-561.

-6 Fortune B, Wang L, Cull G, Cioffi GA: Intravitreal colchicine causes decreased RNFL birefringence without altering RNFL thickness. Invest Ophthalmol Vis Sci 2008;49:255-261.

\section{KARGER}

E-Mail karger@karger.com

www.karger.com/oph
(2) 2016 S. Karger AG, Base

0030-3755/16/235-0184\$39.50/0
Mustafa Kosker, MD

Department of Ophthalmology

Diskapi Yildirim Beyazit Training and Research Hospital

TR-06450 Ankara (Turkey)

E-Mail mustafakosker0@gmail.com 